\title{
Literatura, afeto e masculinidade: uma leitura de obras de Ondjaki e Mia Couto
}

DOl: http://dx.doi.org/10.21165/el.v49i1.2631

\section{Everton Fernando Micheletti ${ }^{1}$}

\section{Resumo}

O afeto marca grande parte das obras do escritor angolano Ondjaki e do escritor moçambicano Mia Couto, muitas vezes caracterizado pelas relações de gênero. Neste artigo, são analisadas as relações afetivas que envolvem a masculinidade, especialmente no âmbito das personagens, procurando-se verificar se a perspectiva é conformadora ou crítica quanto à ordem da divisão de gênero, a hegemonia masculina e consequente violência. Para tanto, são abordadas várias obras de modo a se identificar as características recorrentes de tais relações e as diferenças de perspectiva entre os dois autores, tomandose como referenciais teóricos principais os textos de Connell $(2005,2002,1995)$ sobre as "masculinidades", de Sedgwick (1985) sobre o "desejo homossocial masculino" e, também, alguns conceitos e pressupostos das "teorias do afeto" (SEIGWORTH; GREGG, 2010; ANDERSON, 2009) que podem contribuir com as discussões sobre masculinidade e literatura.

Palavras-chave: literatura africana; Ondjaki; Mia Couto; masculinidade; afeto.

1 Universidade de São Paulo (USP), São Paulo, São Paulo, Brasil; efmicheletti@gmail.com; https://orcid.org/0000-0003-1526-3332. 


\title{
Literature, affection, and masculinity: a reading of the works of Ondjaki and Mia Couto
}

\begin{abstract}
The affection marks most books of the Angolan writer Ondjaki and of the Mozambican writer Mia Couto, often characterized by gender relations. In this article, the affective relationships involving masculinity are analyzed, especially within the scope of the characters, in order to verify if the perspective is conforming or critical regarding the order of the gender division, the male hegemony and the consequent violence. To this end, several works are approached to identify the recurrent characteristics of such relationships and the differences of perspective between the two authors, taking as main theoretical references the texts of Connell $(2005,2002,1995)$ on "masculinities", Sedgwick (1985) on the "male homosocial desire", and also some concepts and assumptions of the "affect theories" (SEIGWORTH; GREGG, 2010; ANDERSON, 2009) that may contribute to the discussions about masculinity and literature.
\end{abstract}

Keywords: African literature; Ondjaki; Mia Couto; masculinity; affection.

\section{Introdução - Afeto, masculinidade e literatura}

O afeto caracteriza grande parte das obras de Ondjaki e de Mia Couto de várias formas. No âmbito das personagens, destacam-se as relações entre crianças e jovens, entre estes e os mais-velhos, entre homens e mulheres. Conjuntamente, há as relações afetivas espaço-temporais, em que as cidades e vilas aparecem caracterizadas pelas memórias da infância ou por outros acontecimentos, como nos períodos de tensão antes e depois da independência em Angola e em Moçambique, ampliando-se o afeto, dessa maneira, para a nação. Logo, se o afeto marca a literatura dos dois autores pelos aspectos positivos, por exemplo, pela solidariedade entre personagens, ele também aparece em seu aspecto negativo, com as situações de violência. Como demonstrado pelas "teorias do afeto", ele envolve "promessa e ameaça", surge "no entrelugar", isto é, "nas capacidades de agir e sofrer a ação", de "afetar e ser afetado" em um "mundo de encontros... ambíguos e mistos" que "impelem e repelem para o pior e para o melhor", de modo sempre dinâmico e processual (SEIGWORTH; GREGG, 2010, p. 1-10)².

Com essa complexidade afetiva, a do entrelugar que reúne as várias formas entre positivas e negativas do afeto, identifica-se a masculinidade como um dos elementos que incidem nas relações afetivas em textos de Ondjaki e de Couto. Consideradas em suas múltiplas configurações (CONNELL, 2002), a masculinidade aparece nas relações de personagens masculinos entre si, por exemplo, quando um mais-velho ensina algo para os mais jovens

2 Tradução livre (deste e dos demais textos originalmente em língua inglesa). 
dentro de uma visão masculina de mundo, muitas vezes objetificando as mulheres, e, por conseguinte, nas relações com as personagens femininas, estando, em seu extremo negativo, os casos de estupros. A "masculinidade", portanto, é relacional, isto é, configurase "em relação" à feminilidade dentro da ordem de gênero que divide homens e mulheres, assim como divide os homens entre si, entre as masculinidades hegemônicas e as subordinadas (CONNELL, 2005).

Diferentemente do que sempre se difundiu, a masculinidade não é uma "essência", "uma entidade fixa encarnada no corpo", as "masculinidades são configurações de práticas que são realizadas na ação social" e "podem se diferenciar de acordo com as relações de gênero em um cenário social particular" (CONNELL; MESSERSCHMIDT, 2013, p. 250). Já a "masculinidade hegemônica" envolve tanto "um padrão de práticas" de dominação de homens sobre mulheres, o que possibilita a continuidade da dominação e está na base do "patriarcado", quanto de homens sobre outros homens, em relação às "masculinidades subordinadas" (CONNELL; MESSERSCHMIDT, 2013, p. 245). A "hegemonia" não é entendida como algo essencial ou natural dos homens, mas, sim, como uma construção, o que requer constante reconstrução, por isso, pode ser questionada, "desafiada por mulheres", sendo a hegemonia "historicamente uma relação móvel" (CONNELL, 2005, p. 77). Nota-se a semelhança da "hegemonia" com a própria "masculinidade", o que se deve às estruturas de poder serem generificadas (CONNELL, 2005, p. 73-74), estando a sexualidade implicada nos mecanismos de poder (FOUCAULT, 1999).

Sendo assim, "afeto" e "masculinidade" convergem em alguns pontos, pois ambos são difíceis de delimitar conceitualmente, constituem-se por dinâmicas, são processuais e relacionais, envolvem sujeito e corporificação. Um aspecto que vale esclarecer é quanto a uma distinção feita, por alguns "teóricos do afeto", entre afeto e emoção, ainda que implicados, em que o primeiro estaria no âmbito potencial do sujeito, sendo inconsciente, indeterminado, sem significado, enquanto a emoção caracterizaria o já tornado consciente, determinado, significativo. Anderson, em sua abordagem sobre as "atmosferas afetivas", opõe-se a uma separação de tal forma, considerando que o "sem significado" e o "com significado" se "misturam", que se é afetado pelas "ambiguidades de afeto/emoção, por aquilo que é determinado e indeterminado, presente e ausente, singular e vago" (ANDERSON, 2009, p. 80).

Nesse sentido, na literatura, interessam as relações afetivas caracterizadas pela masculinidade em suas várias formas, em que o termo "afeto", mais abrangente e aberto do que "emoção", ainda que inter-relacionados, mostra-se adequado para dar conta das variadas nuances dessas relações. Pode-se verificar, portanto, se a perspectiva nas obras é conformadora ou crítica quanto aos problemas que incidem no afeto e na masculinidade, com atenção tanto às personagens - às quais se dará ênfase neste artigo - quanto aos espaços e tempos, à linguagem (gírias, expressões coloquiais) e à estrutura narrativa (narrador, focalização). É possível, também, dar atenção à recepção, às relações afetivas 
no processo "autor-obra-público" e como se caracterizam pela divisão de gênero (autores homens, público feminino), bem como quanto a uma provocação por meio da afetividade para engajar o público no sentido do que afirma Sartre (2004), podendo-se pensar em ambos os escritores como produtores de uma literatura do afeto.

\section{Relações afetivas entre personagens masculinos}

Uma das dimensões do afeto caracterizado pela masculinidade na literatura está nas relações de personagens masculinos entre si, especialmente pelas relações entre as personagens infantis, os "mais-novos", ou entre estes e os idosos, os "mais-velhos". Representativa deste último caso, tem-se a relação entre o ancião Tuahir e o adolescente Muidinga no romance Terra sonâmbula (COUTO, 2007). Em meio ao difícil período de guerra pós-Independência em Moçambique, Tuahir encontra o menino num campo de refugiados e passa a cuidar dele, seguindo juntos pelo país em ruínas. Eles fazem moradia num ônibus destruído próximo a uma estrada, onde encontram os cadernos de Kindzu, um dos mortos que enterram. Enquanto cuidam um do outro, leem os cadernos, havendo um processo de aprendizagem mútua, o mais-novo sabe ler e realiza as leituras, o maisvelho faz a mediação oral entre as tradições e memórias sobre o país, ao que se soma a experiência de Kindzu, outro personagem masculino. Em certo momento, ocorre um jogo de espelhamento entre Muidinga e Kindzu, o que leva Tuahir a pensar e até mesmo se posicionar sobre os vínculos afetivos que vem estabelecendo com o menino:

[...] o moço the pede que se junte a ele numa estranha brincadeira.

- Tio, vamos fazer um jogo. Vamos fazer de conta que eu sou Kindzu e o senhor é o meu pai!

- Seu pai?

- Sim, o velho Taímo.

Tuahir negou. O tal Taímo era um falecido. E com os falecidos nunca é bom brincar. (COUTO, 2007, p. 153-154)

Há tentativas de recuperação social, em meio à guerra que a tudo desestrutura, via modelo familiar das continuidades entre sujeitos masculinos, recuperação que passa pelos papéis sociais (pai/filho). 0 afeto de Tuahir caracteriza-se pela ambiguidade, ele hesita, ao longo da narrativa, entre uma maior aproximação e a manutenção de certo distanciamento. O motivo pode estar na perda do filho que foi trabalhar nas minas da África do Sul e não mais retornou, cujo nome, Muidinga, ele deu ao menino, daí o medo de

3 Em grande parte dos textos de Couto e Ondjaki, há o uso do itálico para as falas das personagens, além de se utilizarem da liberdade em relação às normas da língua portuguesa, por isso é comum que se notem "desvios" de vários tipos, alguns destes caracterizando o afeto: "ti Chico" [tio] (ONDJAKI, 2007, p. 97). 
uma nova perda e, logo, de uma inevitável despedida, pois o menino estava sem memória e poderia recuperá-la, descobrindo ter família, ter pai. Também, subentende-se que é uma forma de aprendizagem que ele impõe ao mais-novo, para ser forte e resistir no país em guerra. De qualquer modo, ser "duro" e evitar demonstrar sentimentos são atributos masculinos, não havendo, nesse espelhamento entre pais e filhos, uma ruptura na ordem de gênero; Tuahir, por exemplo, não realiza ações maternais, diferente de Kindzu que, embora seja predominantemente caracterizado pela masculinidade - seu nome vem de uma planta e é um semeador para trazer a vida de volta àquela terra ferida "feminina" - , ao final canta "os embalos" maternos (COUTO, 2007, p. 203).

No conto "O cego Estrelinho" (COUTO, 2012a), o afeto entre o personagem-título e seu guia Gigito é evidenciado pela proximidade corporal, em que a mão do guia "era repartidamente comum, extensão de um no outro", sendo considerado que a memória "de Estrelinho tinha cinco dedos e eram os de Gigito postos, em aperto, na sua própria mão" (COUTO, 2012a, p. 21). Tal aspecto do vínculo afetivo dos dois é reforçado quando Estrelinho, na hora de dormir, "aninhava sua mão na mão do guia. Só assim adormecia" (COUTO, 2012a, p. 22). Em Os transparentes (ONDJAKI, 2013), também há um personagem cego, mais-velho, que é ajudado por outro, o jovem VendedorDeConchas, compartilhando o ponto de vista masculino sobre as mulheres e outros assuntos enquanto caminham de braços dados por lugares de Luanda. O afeto, nesses casos, torna-se mais visível por ir à contramão de certa característica da masculinidade: a que impõe limites corporais entre homens. Entre as razões para isso estão a homofobia e o machismo, pois, para definir a masculinidade "real", é preciso distanciá-la do rejeitado, em que "o limite entre heterossexual e gay é manchado pelo limite entre masculino e feminino", com os homens gays vistos como abjetos por serem feminizados (CONNELL, 2005). Mas, faz parte da masculinidade, também, uma "irmandade", um apoio mútuo entre sujeitos masculinos, permitindo uma aproximação corporal como "amigos", "irmãos", o que acaba por mostrar o lado contraditório da masculinidade. Sedgwick (1985) utiliza o termo "homossocial" para essa "irmandade", para esse forte vínculo entre os homens (heterossexuais), de que faz parte, sobretudo por relações de poder, o confronto constante com a homossexualidade potencial. Essa "contradição" de uma "homocultura hétero" sempre conter o que evita (homossexualidade) aproxima-se de uma das linhas argumentativas de Foucault (1999) em sua análise histórica da sexualidade: o que se pretende reprimir acaba por ser algo sempre presente, até mesmo servindo como parte dos mecanismos de poder, isto é, "produz-se" o outro "desviante", principalmente pelos discursos (religioso, científico), para, ao combatê-lo, reafirmar o poder e a hegemonia do "normal".

No entanto, se há a solidariedade entre os sujeitos masculinos, ela pode ser decorrente de situações de violência, principalmente no contexto do colonialismo. No conto "O embondeiro que sonhava pássaros" (COUTO, 2013), a amizade entre um menino branco e um vendedor de pássaros negro mais velho incomoda o "mundo colonial", anos antes da independência. $\mathrm{O}$ afeto entre esses dois personagens masculinos pelo encantamento sobre o domínio dos pássaros funciona como metáfora para a nação, pois, ao final, quando 
os colonos colocam fogo num embondeiro (baobá) acreditando lá estar o vendedor, o menino Tiago é que lá estava e, simbolicamente, torna-se árvore ao morrer, o menino branco enraíza-se no solo africano. Na crônica "O dia em que fuzilaram o guarda-redes da minha equipa" (COUTO, 2008), tem-se um bar caracterizado como um espaço masculino: reunião de amigos, bebidas, mesa de jogos, reforçado pela proximidade de um quartel português (período colonial), logo, com a presença de soldados e prostitutas. A violência manifesta-se simbolicamente: quando os bonecos do futebol de mesa aparecem pintados com a cor negra, é despertada a fúria de um soldado que atira no boneco/goleiro. Ao mesmo tempo em que a violência mantém a hegemonia masculina nas estruturas de poder, os sujeitos masculinos também sofrem nesse processo, estando aí implicadas as diferenças de classe social e o racismo, levando-se ao que se vem denominando atualmente de "masculinidade tóxica"4

No romance Um rio chamado tempo, uma casa chamada terra (COUTO, 2003), o enredo estrutura-se pela relação entre dois personagens masculinos, Mariano e Marianinho, a princípio avô e neto, ao final sendo revelado que eram pai e filho, no contexto da desorganização social pós-independência em Moçambique. Com a morte do "avô" e atendendo a uma exigência deixada por ele, o jovem tem de retornar à vila Luar-do-Chão para realizar o funeral, lá começa a "receber" cartas do "avô" morto enquanto escreve, isto é, o mais-velho escrevia pelas mãos do mais-novo. Com isso, descobre uma série de acontecimentos do passado, nesse processo em que o "avô" acerta contas com a história para conseguir ser enterrado e "descansar em paz". O nome igual já evidencia a transmissão de determinadas funções do homem mais velho ao mais jovem, como quando dizem a este: "você prometa ter cuidado. [...] você recebeu o nome do velho Mariano. Não esqueça.", sobre o que ele conclui: "não apenas eu continuava a vida do falecido. Eu era a vida dele." (COUTO, 2003, p. 22). Na última carta, o "avô"/pai declara: "Você é meu filho. Meu maior filho pois nasceu de um amor sem medida. [...] a vida escreveu no seu nome meu próprio nome" (COUTO, 2003, p. 260).

O conflito na narrativa, em termos gerais, decorre da relação entre as tradições e a modernidade, sendo que o "avô", querendo evitar que todas as tradições se desfizessem, contraditoriamente rompe com parte delas para que o jovem, embora já vivendo no meio urbano, mas com melhor índole do que outros homens da família, garantisse certa preservação, ao menos numa perspectiva das tradições que se mantêm porque se atualizam (HALL, 2003). Mas, nessa "atualização", ainda prevalecem as masculinidades hegemônicas, a transmissão se dá entre sujeitos masculinos, inclusive o fim da interdição

4 Os "efeitos tóxicos" da masculinidade, segundo Connell (2002, p. 25-26), além de incidir na vida dos outros (estupro, violência doméstica contra as mulheres, violência homofóbica, racismo), atingem a vida dos próprios homens, incluindo os altos índices de ferimentos em acidentes de carro, vício em drogas, uso inadequado dos serviços de saúde, prisão $(90 \%$ dos presos eram homens na Austrália e Estados Unidos em 1997). Essas "desvantagens" são as "condições para as vantagens" na manutenção da masculinidade hegemônica (CONNELL, 2005). 
ao enterro do morto liga-se à realização do ato sexual com uma mulher como quem domina o lugar, como o jovem conclui: "Afınal, eu entendo: eu não podia possuir aquela mulher enquanto não tomasse posse daquela terra. Nyembeti era Luar-do-Chão" (COUTO, 2003, p. 253). O "re-enraizamento" do jovem é conduzido pelo mais-velho em termos de uma masculinidade que garante algum tipo de retomada da ordem naquele meio social, ainda que fosse uma "nova ordem", o que se dá por meio de uma relação afetiva masculina reforçada pela duplicidade do "avô"/pai.

Em grande parte dos textos de Ondjaki, é marcada, também, a presença dos mais-velhos e mais-novos, com os avós, tios, professores, pais, amigos, sendo o afeto o elemento principal e, pode-se dizer, estruturante das narrativas. É o que se observa nos títulos com os "camaradas" e "os da rua", muitas vezes com um conjunto de diferentes obras sob o mesmo ponto de vista das memórias de infância e adolescência, formando um grande "tecido" intertextual, reaparecendo os amigos, os parentes e até mesmo havendo a reiteração de episódios, em que as memórias individuais misturam-se com as memórias coletivas da cidade e do país. Com a presença de pessoas "reais", como o tio Rui, referência ao escritor Manuel Rui, tio de Ondjaki, possuidor dos bigodes em A bicicleta que tinha bigodes (2012), e a avó Agnette, personagem-título de AvóDezanove e o segredo do soviético (2009), além das narrativas em que o menino narrador "assume" seu nome, Ndalu (nome verdadeiro de Ondjaki), ou apenas Dalinho, apelido que ratifica a afetividade também no campo da linguagem, pode-se considerar que grande parte de suas obras aproxima-se ou, mesmo, configura-se como "autoficção" 5 .

Em Bom dia camaradas (ONDJAKI, 2006), o termo "camarada" contém a ambiguidade do afeto, pois, ao mesmo tempo em que o menino narrador assim denomina algumas pessoas próximas, utiliza de modo irônico em outros casos por ser um uso repetido advindo da luta anticolonial e que já parece desgastado. Nessa obra, uma das relações afetivas que sobressai é a do menino com o "camarada António", o mais-velho empregado de sua casa, visto que se trata de uma família de "classe média pós-colonial" (RUFFATO, 2006). É com essa relação que se abre e se desenvolve a narrativa, havendo constantes referências aos cheiros do camarada e da cozinha, o que caracteriza sinestesicamente

50 termo "autoficção" foi utilizado por Doubrovsky para denominar, de modo geral, um tipo de narrativa autobiográfica e literária ao mesmo tempo, questionando os limites entre uma autobiografia "real" e uma ficcional, afirmando: "Toda autobiografia, qualquer que seja sua 'sinceridade', seu desejo de 'veracidade', comporta sua parte de ficção", assim, "autobiografia e autoficção, a narrativa de si é sempre modelagem, roteirização romanesca da própria vida." (DOUBROVSKY, 2014, p. 121-124). Coincidente com a "guinada subjetiva" a partir dos anos 1970, quando houve uma espécie de resposta à "morte do sujeito", produzindo-se no campo da memória "um movimento de restauração" que "poderia se chamar 'O sujeito ressuscitado"' (SARLO, 2007), o termo "autoficção" tem gerado discussões, porém, para as obras de Ondjaki, há menos problemas porque ele publica como literatura, já indicando que as referências "reais" estão mais no âmbito de uma ficcionalização do "eu". 
as memórias da infância e dos afetos, e, assim como Muidinga que pede para brincar de ser Kindzu (COUTO, 2007), o menino também brinca de ser o camarada António (ONDJAKI, 2006). As relações com os empregados, incluindo também o motorista da família, o camarada João, porém, não avançam numa problematização das diferenças de classe social, permanecendo mais no campo afetivo da visão "inocente" da infância.

A masculinidade, algumas vezes, aparece implicitamente normatizando as relações e, mesmo com o afeto do menino pelas mulheres da família, não há questionamentos ou rupturas na ordem da divisão de gênero. Um dos momentos em que se podem identificar as "formações" da masculinidade ou "masculinização" ocorre quando acaba uma gravação na Rádio Nacional com vários meninos e eles fazem "troca de disparates e de estigas": "Foi com eles que aprendi aquelas: 'engoliste cócega, arrotaste gargalhada, quem acorda primeiro na tua casa é que põe cueca, bebeste água de bateria, começaste a dar arranque'..." (ONDJAKI, 2006, p. 38). A "estiga" é uma "forma de ridicularizar outrem, usada essencialmente no discurso infantil, podendo mesmo assumir um caráter acintoso" (ONDJAKI, 2006, p. 140), com um jogo de palavras de tom muitas vezes agressivo. Essa competitividade da estiga funciona, no microcosmo cotidiano infantil e adolescente, como uma formação de base de disputa entre masculinidades (hegemônica e subordinada), pois, como afirma Connell (2002, p. 18), as masculinidades "passam a existir na ação das pessoas [...] na conduta cotidiana", visto que "fazemos gênero" na "vida diária". Nota-se a complexidade do afeto, em que se tem uma relação ao mesmo tempo positiva, prazerosa nessa reunião de meninos, e negativa, com uma brincadeira em que se "atacam" verbalmente.

Nesse sentido da ambiguidade, o afeto aparece quando chegam as férias e o menino narrador sente saudades dos acontecimentos bons e ruins na escola, das brincadeiras e dos "camaradas professores", "de jogar estátua nos corredores embora quando se levasse uma bem esquentada as costas ficassem a arder" ou "jogar estica" até serem "apanhados pelo camarada subdiretor" e levarem "todos duas reguadas em cada mão" (ONDJAKI, 2006, p. 94). A complexidade do afeto está mesmo na dificuldade em separar o positivo e o negativo, visto que um contém o outro na configuração das memórias daqueles que eram, como ele afirma: "os melhores tempos das nossas vidas" (ONDJAKI, 2006, p. 94). E, do mesmo modo, ao final da narrativa, ele sofre ao saber da morte do "camarada António", recordando os sons e cuidados do empregado, em seguida vêm outras lembranças junto com a chuva que começa a cair, tem a percepção cíclica da vida e termina sorrindo: "Sorri só." (ONDJAKI, 2006, p. 136-137).

Em Os da minha rua (ONDJAKI, 2007), tem-se o mesmo menino narrador trazendo as memórias da infância e adolescência, continuando ou ampliando o livro Bom dia camaradas (ONDJAKI, 2006), pois alguns acontecimentos reaparecem, são recontados num entretecer das várias obras narrativas do autor. Nesse outro livro, a divisão em episódios é mais marcada, com mais situações em que se têm a divisão de gênero 
(masculino/feminino) e características da masculinidade. As relações entre os sujeitos masculinos mantêm-se com estigas, com certa agressividade consentida e preferência por filmes de ação e luta, como no seguinte trecho: "A conversa no muro aquecia. Dois ou três ficavam a estigar, os outros riam só. O Paulinho contava filmes do Bruce Lee, do Trinitá e dos ninjas..." (ONDJAKI, 2007, p. 38). Existe todo um processo de "masculinização" em que os meninos são incentivados a terem algumas atitudes violentas, aproveitando-se "a energia" e "a dimensão ativa de uma pessoa em crescimento" somadas aos "prazeres e emoções de se entrar em um mundo generificado e de se apropriar da masculinidade" (CONNELL, 1995, p. 190), o que envolve as "masculinidades exemplares" das produções culturais como os filmes (CONNELL, 2005, p. 214). Em outro episódio, quando o menino narrador vai ao cinema e vê um filme de ação, fica impressionado pela forma como o personagem/herói "batia male!, ninguém Ihe aguentava" e o bandido Kisse tinha levado "só bué de pontapés na cabeça até desmaiar", fazendo com que o menino os quisesse imitar: "Voltamos para casa. Fui o caminho todo a imitar os golpes e pontapés..." (ONDJAKI, 2007, p. 33-34).

No episódio da viagem ao Namibe, ocorre uma série de aprendizagens da masculinidade em meios às relações afetivas, por exemplo, quando o menino aprende sobre a caça com os primos de seu pai: "primo Zequinha [...] ensinou-me duas técnicas de caçar rolas, uma era pôr visgo nas árvores [...], e a outra, que eu gostei mais, era usar a arma de chumbo..." (ONDJAKI, 2007, p. 49). Na sequência, quando os homens adultos retornam da caça com um olongo, espécie de antílope que caçaram, o menino fica admirado com o animal e com as armas: "eu nunca tinha visto um animal tão grande e tão pesado, e também nunca tinha visto umas armas tão compridas" (ONDJAKI, 2007, p. 51). A apropriação dessa masculinidade exemplar confirma-se em seguida, quando são feitas fotografias e o menino imita os caçadores:

No último dia de manhã é que meu pai se lembrou de tirar fotografias a todos. Eu também aproveitei uns pássaros que o primo Zequinha já tinha conseguido matar, pus todos assim no chão perto dumas pedras e fui buscar a arma de chumbo. Fiz um poster de joelho no chão estilo filme de cobói e o meu pai tirou uma foto que eu tenho até hoje, também com chapéu que me ficava grande mas que tinha assim aquele estilo do Trinitá. (ONDJAKI, 2007, p. 51).

A exemplaridade dos caçadores e dos "cowboys" ("cobói"), do personagem Trinitá dos filmes de faroeste italiano dos anos 1970, funciona no processo de agenciamento dos meninos em termos de masculinidade por conter uma série de características atribuídas ao "ser masculino" - agressividade, agilidade, violência, racionalidade, predisposição ao uso de armas - mesmo que não se tornem necessariamente caçadores ou "cowboys". É o momento, não de simples transmissão, mas de "apropriação ativa do que é oferecido", de "engajamento", quando "o menino assume o projeto da masculinidade hegemônica como seu" (CONNELL, 2005, p. 122). Para tanto, é necessário eliminar dele o que seria próprio 
do feminino, como acontece em outro episódio, na escola, quando fazem a leitura do texto "Nós matámos o cão-tinhoso" do escritor moçambicano Luís Honwana. O menino conta sobre a vontade de chorar durante a leitura, mas que não podia: "O Olavo avisou: 'quem chorar é maricas então!', e os rapazes todos ficaram com essa responsabilidade de fazer uma cara como se nada daquilo estivesse a ser lido." (ONDJAKI, 2007, p. 134). 0 menino sente a pressão da masculinidade quando a professora pede a ele para terminar a leitura: "ela [...] estava a me castigar nessa responsabilidade de falar do Cão Tinhoso sem chorar", assim, ele segue contando como teve de resistir e conclui: "Na oitava classe, era proibido chorar à frente dos outros rapazes." (ONDJAKI, 2007, p. 134-135).

Na obra Quantas madrugadas tem a noite (ONDJAKI, 2010), há algumas mudanças estruturais, o narrador personagem é um homem adulto contando uma história a um "avilo" (amigo) em um bar, enquanto tomam cerveja. Essa história principal contada desenvolve-se com digressões, comentários, interrupções e retomadas, sendo uma das obras com as marcas da masculinidade mais presentes, inclusive pela linguagem, pois o texto é atravessado por gírias que, em sua maioria, são próprias do universo masculino. Aparecem, ainda, alguns personagens e referências a episódios de outras obras, mas a instância narrativa e o foco são outros. A obra é dedicada a João Vêncio, um personagem de Luandino Vieira (1987), que é um dos mais emblemáticos quanto à masculinidade nas literaturas africanas em língua portuguesa. O afeto faz parte das relações entre os sujeitos masculinos, em toda a sua complexidade, como se percebe na apresentação do amigo com nanismo pelo narrador:

Olha, esse que eu te falei, Burkina, mô camba, era um ndengue muito craque, via mais que todos à noite, tipo gato, Ihe estigávamos de feiticeiro, o muadiê só ria, [...] Yá, nós alturamos, o gajo nada, se male mesmo, primeiro era só cambutismo, lhe estigávamos só dum coro, depois desistimos, aquilo já não era matéria de estiga - respeito só. O muadiê ficou grosso, mas só pra cada lado, e batia male, começou a ficar tipo maboque, azedado, quase não falava. Mas era potente nas damas, xaxeiro de competência reconhecida até na Ilha, único que num era kiungueiro, só kinjango dele, avilo!, tava nos meter respeito quanto mais nas damas! (ONDJAKI, 2010, p. 14).

Por meio de uma linguagem específica desse grupo de homens, com gírias advindas da hibridização do português e de línguas africanas, especialmente o kimbundu, notam-se os elementos que caracterizam a masculinidade, como: a capacidade de briga ("batia male") e os atributos sexuais ("xaxeiro", galanteador; "kiungueiro", não circuncidado; "kinjango", pênis). Outra parte das gírias reforça a afetividade masculina: "mô camba" (meu amigo), "ndengue"/"candengue" (garoto/menininho), "muadiê" (homem, rapaz, gajo). Mais uma vez, tem-se a estiga fazendo parte da afetividade ambígua, com uma agressividade no estabelecimento de vínculos entre meninos e, depois, homens, enquanto os atributos sexuais funcionam como uma compensação à baixa estatura na garantia da masculinidade. 
Há episódios, nessa obra, de uma solidariedade masculina diante de um "mundo masculino", como no caso em que Jaí, perseguido por uma multidão por ser albino, recebe a ajuda dos amigos. "Mundo masculino" porque se têm os elementos socioculturais atribuídos à masculinidade: perseguição policial, armas e semelhança com "filme de cobói" (ONDJAKI, 2010, p. 28-29). Na sequência, Burkina aparece com seu candongueiro (tipo de táxi) e salva Jaí, havendo a seguinte conclusão: "o albino Jaí mesmo fez o sorriso mais estranho mas mais bonito da vida dele, nunca tinha lhe sabido tão bem ver aquela cara feia do anão BurkinaFaçam" (ONDJAKI, 2010, p. 29). O afeto masculino, em sua ambiguidade, precisa pôr barreiras à aproximação, o "querer bem" - sorriso "mais bonito", "sabido tão bem" - não pode ir longe demais, cujo ponto extremo seria o interesse sexual, daí que se reforça o olhar sobre o abjeto: o "sorriso mais estranho", a "cara feia". Esse aspecto dúbio da masculinidade, do afeto que se dá por proximidade e distanciamento, pode ser observado em outro episódio da narrativa, quando Burkina é confrontado na "estiga de não saber nadar", afoga-se e é socorrido:

[...] quem ia pinar pra Ihe buscar? Sabes? AdolfoDido. [...] Saltou, mergulhou, demorou [...] e o Burkina sem ares pra respirar, só aí na areia, não sabíamos que fazer

tem que dar beijo da boca!

mas quem ia dar beijo na cara feia do Burkina?

AdolfoDido de novo!, isso já foi coragem mesmo, tenho que admitir, Burkina então é um gajo feio, meu, não dá pra lhe beijar assim, lábio de homem com homem. Mas foi. E mudos, nem falamos mais. Voltamos só assim da praia, nosso segredo, e o Burkina, que não tinha palavras, chorava só: não era lágrima de medo, aquilo eram emoções, lágrima do agradecimento que as palavras não podem falar. Você cala, chora só; nós Ihe entendemos. (ONDJAKI, 2010, p. 19).

A manutenção da masculinidade envolve um controle dos corpos masculinos, impõemse os limites corporais entre os sujeitos masculinos para enfrentar a potencialidade sempre presente de o afeto atingir o nível de desejo e/ou realização sexual, sendo uma das estratégias recorrer ao abjeto ("gajo feio"). A potencialidade torna-se evidente nesse trecho porque o afogamento obrigou um deles a transpor o limite e realizar o beijo entre homens, tiveram de se ver confrontados pelo desejo entre eles, mas a interdição ao desejo se mantém pelo silêncio ("mudos") e segredo. Viram-se, também, confrontados em sua masculinidade - a do "homem não chora" - pelas lágrimas de "emoções", gerando uma compreensão mútua pelo afeto ("nós Ihe entendemos"). Para Sedgwick (1985), ao mesmo tempo em que a hegemonia masculina se constrói pela homofobia, há um continuum histórico no campo de um "desejo homossocial masculino", sendo o "desejo" entendido à semelhança do uso psicanalítico da "libido", isto é, como força social e afetiva mais ampla, em que está implicada a sexualidade na estruturação do poder. O continuum "homenspromovendo-os-interesses-dos-homens" parece próximo de algo como "homensamando-homens", sendo o heterossexismo um meio de dominação sobre as mulheres 
para manter e transmitir o poder patriarcal entre eles (SEDGWICK, 1985). Assim, a busca por controlar a liberdade sexual sob a égide da heteronormatividade segue como algo constante, contínuo, como é próprio da "hegemonia", pois não se trata de algo essencial e natural dos sujeitos, mas, sim, construído e reafirmado socialmente em termos das relações de poder generificadas, em que os homens enfrentam a contradição de um "desejo" comum e marcam uma divisão de gênero em que, muitas vezes, eles se impõem como sujeitos e as mulheres são tidas como "objetos".

\section{Relações afetivas entre personagens masculinos e femininos}

As relações entre personagens masculinos e femininos ocorrem de diversas formas, havendo uma marcada divisão social dos gêneros tanto em termos das tradições ancestrais africanas quanto no que diz respeito à modernidade. A reafirmação da masculinidade hegemônica segue em curso, continua "ensinando" os diferentes papéis para meninos e meninas, ao mesmo tempo em que as contradições são mantidas. Semelhante ao beijo entre Burkina e Adolfo, a esse ato ambíguo de salvar um amigo numa aproximação corporal geralmente interdita, há o caso em que Tuahir "ensina" a Muidinga sobre as mulheres e o sexo por meio da masturbação:

- Te falta é uma mulher, disse o velho. Estiveste a ler sobre essa mulher, a tal Farida. Deve ser bonita, a gaja.

As mulheres, em instante, ficaram tema. Mulheres é bom quando não há amor, [...] Vale a pena uma puta, miúdo. Gastamos o bolso, não o peito. Numa puta não pomos nunca o coração. [...] Contempla o miúdo, Ihe adivinha a idade de começar namoros. E sorri recordando a cena das velhas violando o rapaz. O rapaz merecia outras iniciações.

- Espera, miúdo. Deixa eu sentar perto.

Se arruma na beira no assento de Muidinga. Mete a mão entre as virilhas do rapaz. Aos poucos the vai desapertando a breguilha.

- Agora pensa nas meninas. (COUTO, 2007, p. 123-124).

Essa prática de ensinamento da sexualidade entre homens, que, atualmente, para muitos, poderia ser entendida como homossexual, como não-masculina, contém historicamente elementos de masculinidade, tendo sido comum em algumas sociedades, como a grega, funcionando no processo de formação dos mais jovens para exercerem o papel social masculino quando adultos, o que incluía, muitas vezes, a formação como guerreiros. A continuação da masculinidade passa por essa transmissão/aprendizagem entre corpos masculinos, sendo que, no caso supracitado, projetando o desejo em relação às mulheres, sendo elas objetificadas, isto é, tomadas como "objetos" para a satisfação dos homens, divididas entre as "amadas" e as "putas", e, não, como "sujeitos" com ação autônoma e conforme suas vontades. A referência às "velhas violando o rapaz" diz 
respeito a um episódio anterior, quando Muidinga se perde e entra no caminho das "idosas profanadoras" que faziam um ritual agrícola interdito aos homens, elas castigam o jovem violentamente com seus corpos considerados abjetos: "as usadas carnes, enrugadas até os ossos, os seios pendentes como sacos mortos [...] se seguem num amontanhado de corpos, gorduras e pernas" (COUTO, 2007, p. 101). A objetificação das mulheres positiva e negativa, pelos padrões do corpo desejável e do corpo repugnante (como as idosas) - por uma "irmandade masculina" ocorre também em Quantas madrugadas tem a noite (2010), como no trecho a seguir:

Agora me é difícil odiar alguém, muadiê, e quando digo filhas da puta nessas damas que foram minhas, [...] o cheiro que elas querem é do mel do cumbu, as pensões [...], e mesmo o Burkina, muita gente não entende esse relacionamento dele contente com as putas que, mais que putas, são cambas dele, e ele quer quê, afinal, muadiê?, carinho, festividades no órgão dele do lado esquerdo do peito a se encher assim das alegrias que nunca tinha tido, [...] é só amor derretido no leitemoça dos olhos delas - catorzinhas de já mais idade, num sei como vai ser daqui a tempos, mas têm que pôr novas noções: vintiuminhas, trintiumistas, e daí pra frente, é já com onas - quarentonas, cinquentonas, esquecidonas... (ONDJAKI, 2010, p. 180-181).

A divisão de gêneros é marcada por uma oposição, em que são comparadas as esposas/ ex-esposas que teriam interesse no dinheiro ("cumbu") e as prostitutas mais carinhosas, porém, contraditoriamente, as primeiras são atacadas verbalmente com a denominação das segundas, "filhas da puta", expressão ofensiva de base sexista recorrente em língua portuguesa. Com o ponto de vista narrativo masculino, não há a percepção de que o interesse financeiro das mulheres deve-se mais à hegemonia masculina que se sustenta pela imposição da dependência econômica das mulheres aos homens do que seria responsabilidade pura e simples delas próprias. Objetificadas desde jovens ("catorzinhas"), as prostitutas vão sendo usadas até envelhecerem e serem descartadas ("esquecidonas") por passarem a ter o corpo abjeto como as "idosas profanadoras". Dentro de contexto semelhante da mulher-objeto na prostituição, há um episódio em Os transparentes (ONDJAKI, 2013) em que a homo/bissexualidade feminina de duas prostitutas suecas aparece a serviço dos homens:

[na igreja] as suecas começaram a tirar a roupa

JoãoDevagar fez o mesmo [...], sorriu, deixou cair as calças e passou a mão devagar sobre o seu sexo duro, as suecas [...] tocaram os seus próprios seios para depois tocarem os seios alheios, [...] apertando os mamilos com força sem deixarem de olhar para ele que não se aproximava, beijaram-se as mulheres, lentamente, mas de um modo lascivo que permitisse ao empresário ver as suas línguas e os seus dedos atrevidos alternando o percurso entre as suas bocas molhadas, os seios e os seus sexos com pelos rasos e louros 
o homem fechou os olhos e deixou-se perder no ritmo enérgico das suecas [...]

os fiscais espreitavam a cena pela fresta de uma janela

na outra porta, o pastor brasileiro segurava o sexo na mão, dando ao seu corpo ritmo mais ou menos intenso [...] (ONDJAKI, 2013, p. 376-377).

Em meio a esse jogo entre o sagrado e o profano, com o tom irônico, a masculinidade permanece dominante com a objetificação das mulheres, sendo que, como se nota mais uma vez, contraditória, pois a homossexualidade, geralmente vista como ameaça à masculinidade em termos da heteronormatividade, é aceita desde que para atender ao desejo masculino. Mas, em contraponto a esses casos das prostitutas que, ao menos aparentemente, aceitam sem maiores problemas "servirem" aos homens, há as situações de violência e os estupros em obras de Couto. No romance Antes de nascer o mundo (COUTO, 2009a), a temática central envolve a divisão de gênero levada ao extremo, pois o protagonista decide fundar um "novo lugar", imitando a criação do mundo, sem mulheres, apenas com os filhos "homens". Ao final da obra, é revelado o motivo para essa atitude misógina: a esposa havia sofrido um estupro coletivo e, depois, cometido suicídio. Esta última ação funciona como um enfrentamento à masculinidade hegemônica:

[...] não era viuvez a causa das suas lágrimas. O teu pai chorava por despeito. Suicídio de mulher casada é o vexame maior para qualquer marido. Não era ele o legítimo proprietário da vida dela? Então, como admitir aquela humilhante desobediência? Dordalma não abdicara de viver: perdida a posse da sua própria vida, ela atirara na cara do teu pai o espectáculo da sua própria morte. (COUTO, 2009a, p. 246).

Sob o ponto de vista do marido, do sujeito masculino, a mulher teria sido a responsável pelo estupro devido às roupas que usava, ele é que se sentiu envergonhado com a situação, atingido e "ferido" em sua masculinidade dominadora, por isso havia obrigado que ela ficasse escondida no quarto, sem conversar com ninguém. Após o ocorrido, não houve o afeto necessário a uma recuperação, o afeto em sua forma positiva que se poderia esperar de um marido, pois a masculinidade importou mais, daí que se entenda que o suicídio foi uma forma de confrontar essa dominação masculina. Em A confissão da leoa (COUTO, 2012b), a difícil situação enfrentada pelas mulheres aparece mais marcada, ocorrendo uma mudança estrutural: são intercalados os capítulos narrados por uma personagem feminina e por uma personagem masculina. Dentro do campo do afeto, as agressões de vários tipos, assim como os abusos sexuais e estupros são cometidos por entes familiares, sejam eles maridos ou pais.

Esse romance pode ser considerado como o mais feminista de Couto, pois há uma série de questionamentos sobre a hegemonia masculina, como no trecho em que Mariamar, a protagonista narradora, reflete: "Num instante, estava refeita a ordem do universo: nós 
mulheres, no chão; o nosso pai passeando-se dentro e fora da cozinha, a exibir posse da casa inteira. De novo nos regíamos por essas leis que nem Deus nem o Homem explica." (COUTO, 2012b, p. 26). A masculinidade hegemônica parece ser estabelecida até mesmo no nível divino, daí que se tenha, na versão judaico-cristã, um "Deus pai" que teria criado o "Homem" à sua imagem e semelhança, sendo a mulher um ser secundário. O divino e o mundano se espelham, a religião se constitui por relações afetivas familiares humanas generificadas refletidas nas divinas, sendo que, quando no catolicismo se produziu o culto a Maria, foi com ênfase em sua virgindade, um tipo de valor de pureza próprio da dominação masculina sobre o corpo feminino. Esse questionamento do universo divino sob dominação masculina já havia aparecido no início do romance, quando Mariamar abre a narrativa afirmando: "Deus já foi mulher. Antes de se exilar para longe da sua criação e quando ainda não se chamava Nungu, o atual Senhor do Universo parecia-se com todas as mães deste mundo" (COUTO, 2012b, p. 13). Reunindo ou hibridizando as diferentes perspectivas religiosas (cristãs europeias e africanas), ela questiona o poder divino generificado rasurando a masculinidade de Deus em relação à criação ser também algo feminino, materno ${ }^{6}$.

No romance como um todo, porém, a maternidade aparece em seu aspecto negativo, o que reforça o ponto de vista mais próximo do feminismo, o qual questiona a imposição às mulheres da "obrigação compulsória de reproduzir" e de assumir a maternidade como "essência do seu eu e lei de seu desejo" (BUTLER, 2017). Diferente de outras obras em que Couto se utiliza da maternidade como elemento metafórico, como em Terra sonâmbula (COUTO, 2007), em que as personagens-mães simbolizam uma maternidade mais ampla da terra e da nação; em A confissão da leoa (COUTO, 2012b), percebe-se uma crítica ao imperativo da maternidade, como no seguinte trecho: "Eu, Mariamar Mpepe, estava duplamente condenada: a ter um único lugar e a ser uma única vida. Uma mulher infértil, em Kulumani, é menos que uma coisa. É uma simples inexistência." (COUTO, 2012b, p. 121). Assim, há uma série de acontecimentos na narrativa que evidencia um mundo hostil às mulheres, também há uma personagem que comete suicídio após um estupro coletivo, além de Mariamar revelar que a irmã e ela própria eram estupradas pelo pai. Começam a surgir, também, formas de reagir às tentativas de estupro, como num caso em que tal atitude é representada pela semelhança com as leoas: "toda eriçada, avanço sobre Maliqueto, gritando, cuspindo e arranhando" (COUTO, 2012b, p. 58). Maliqueto é policial, o agente do Estado que deveria garantir a segurança das mulheres e demais habitantes, mas acaba por representar o poder estatal como masculino (CONNELL, 2005).

6 Em grande parte da África, a religiosidade se dá por vínculos afetivos com os antepassados, sendo que a divisão de gêneros era, muitas vezes, problematizada, por exemplo, com entidades andróginas, as quais foram perdendo espaço com o colonialismo. Este, segundo Connell (2005, p. 198), "envolveu um ataque violento e continuado contra a homossexualidade [e bissexualidade] usual de culturas nativas". 
Em Terra sonâmbula (COUTO, 2007), Farida é uma mulher africana que, estuprada por um português, engravida e dá à luz um menino. Nesse caso, a violência por ela sofrida simboliza a violência do colonialismo português que gera a nação moçambicana assim como ela gera o filho - símbolo da nova geração pós-colonial. Isso demonstra como o poder, em suas várias formas, estrutura-se por relações de gênero sob domínio masculino, o que se ratifica com o pitoresco caso, no romance 0 último voo do flamingo (COUTO, 2005), das explosões de soldados na ONU em missão em Moçambique, quando sobrava apenas o órgão genital masculino. Há, nessa narrativa, assim como em Terra sonâmbula (COUTO, 2007), uma crítica ao poder local que se reflete no poder nacional pós-independência por haver um tipo de continuidade, em vez de ruptura, com formas de poder colonial. De certo modo, por mais que possa ser abalado contemporaneamente, 0 poder segue se reorganizando em termos de manutenção da hegemonia masculina, de que faz parte o afeto desde as relações cotidianas familiares e da infância, como base, até as estruturas maiores estatais e globais - incluindo-se a ONU com seus soldados -, do "azul" e do "rosa" que carregam em si as potencialidades de hegemonia de uns e subordinação de outras/outros.

\section{Literatura, masculinidade e o afeto como resposta - considerações finais}

A violência nas relações afetivas envolvendo a masculinidade, como se observa, varia do micro ao macrocosmo social. Na maior parte das obras de Ondjaki, a violência aparece mais nas relações cotidianas, por exemplo, entre amigos na escola ou no bar, em referências aos filmes, e menos em termos políticos, havendo algumas menções irônicas ao governo e a crítica pela difícil situação dos cubanos que atuavam em Angola, com a exceção de Os transparentes (2013), quando ocorre uma mudança e a narrativa incide nos problemas sociais e políticos mais amplos. Nos textos de Couto, a violência é mais marcada, trazida à tona em suas várias nuances, especialmente na forma do poder político colonial e pós-independência, com a ênfase nas relações de gênero, em que pais, maridos, portugueses, administradores moçambicanos, todos de algum modo envolvem-se em situações de violência contra as mulheres.

O afeto, desse modo, em sua "face" positiva, pode ser um recurso de enfrentamento dos problemas e para uma recuperação do meio social, como fazem Tuahir e Muidinga, Farida e Kindzu (COUTO, 2007), Mariano e Marianinho (COUTO, 2003). Como este último caso, alguns pares mantêm-se no âmbito da divisão de gênero, sendo recorrentes as relações masculinistas paternais: Kindzu e o pai morto (COUTO, 2007), o jovem tradutor e seu pai em 0 último voo do flamingo (COUTO, 2005). Pode-se, mesmo, entender a infância, especialmente nos textos de Ondjaki, como uma referência para os adultos sobre as atitudes diante do mundo e o valor dos vínculos afetivos, definida como "reino desprevenido de pensamentos", onde "uma resposta florida poderia nascer, viva e fiel" (ONDJAKI, 2013, p. 10), "como se a infância fosse um ponto cardeal eternamente possível" (ONDJAKI, 2007, p. 150). Além das personagens, o afeto incide no narrador, na 
linguagem, no espaço e tempo como no trecho: "Môs cambas, nome deles, mais velhos e piôs [crianças]: estórias de Luanda - minha Luanda do mô coração" (ONDJAKI, 2010, p. 29). Observa-se aí a "atmosfera afetiva", em que o espaço é "preenchido" pelas relações afetivas, pelas "ressonâncias" entre os sujeitos (ANDERSON, 2009, p. 80), nesse caso os sujeitos masculinos.

As atmosferas afetivas não são "fixas", estão sempre "formando e deformando, aparecendo e desaparecendo" (ANDERSON, 2009, p. 79-80). Elas têm, desse modo, um potencial de transformação, como ocorre com o bar no conto "Os machos lacrimosos" (COUTO, 2009b), até certo tempo um espaço "pleno" da masculinidade, onde amigos se reuniam para contar piadas, mas, depois, onde passam a contar histórias tristes e a chorar, enfrentando o "preconceito macho de que lágrima pública é coisa para o mulherido", que "chorar era coisa de maricas" (COUTO, 2009b, p. 109-110). O texto marca a ruptura que se vem empreendendo com certas formas de masculinidade, incluídas as "tóxicas", com vistas a uma libertação dos homens, nesse caso, com o "direito" de chorar publicamente, "até o Silvestre Estalone, o mais macho e sorumbático da tribo" (COUTO, 2009b, p. 109), até o ator-símbolo da masculinidade no cinema tem sua versão local representando a mudança, como se ratifica na conclusão do narrador: "O pranto é o consumar de duas viagens: da lágrima para a luz e do homem para uma maior humanidade" (COUTO, 2009b, p. 110). No conto "Mulher de mim" (2013) e em outros textos, Couto tem acenado para uma mudança nas relações de gênero sob uma perspectiva próxima do feminismo, porém, ainda, sem maiores rupturas com o heterossexismo, como em "Sapatos de tacão alto" (COUTO, 2012a), em que a degradação de um português no período colonial se dá pelo uso de roupas femininas. Em comparação, as obras de Ondjaki ainda não problematizam ou rompem de modo significativo com a ordem da divisão de gênero.

Sobre o fazer literário, em termos gerais, o compromisso que Couto declara ter diante dos problemas da nação se dá pelo afeto em sua complexidade: "Em todos eles [livros] me confrontei com os mesmos demónios e entendi inventar o mesmo território de afecto, onde seja possível refazer crenças e reparar o rasgão do luto em nossas vidas" (COUTO, 2005, p. 224). Sobre a conclusão de Os da minha rua (ONDJAKI, 2007, p. 150), Ondjaki fala dos "afetos e inquietações revisitadas", dando a entender que as memórias afetivas da infância "impregnam-se" nos adultos, que para delas "sair" seriam necessários mapa e bússola, "como se o tempo fosse um lugar". Expandindo-se aos aspectos "externos", além da nação, o afeto se dá nas relações com os outros escritores e com o público. Seguem implicadas, aí, as relações de gênero, sobretudo pelo grande número de escritores/ homens e o público predominantemente feminino, ainda havendo questões a serem analisadas, por exemplo, com o Prêmio Camões que, em 31 edições, foi concedido a 25 homens, praticamente todos brancos e majoritariamente portugueses e brasileiros. Isto quer dizer que, ao mesmo tempo em que pode ser questionadora, a literatura faz parte das estruturas maiores da sociedade, na qual as masculinidades hegemônicas seguem se reconstruindo juntamente com o heterossexismo, o racismo e a desigualdade de classe social. Mas, no que a literatura pode responder a essa problemática, têm-se as obras de 
Couto e de Ondjaki apontando para o afeto, "engajando" o público pelo afeto (SARTRE, 2004), o qual, em sua complexidade, pode mostrar sua face positiva diante daquelas estruturas com suas faces negativas, em consonância com Bloch (2005, p. 113), com a necessidade de seguir colocando, no horizonte da esperança, o fim das relações de poder generificadas e desiguais.

\section{REFERÊNCIAS}

ANDERSON, B. Affective atmospheres. Emotion, Space and Society, Elsevier, v. 2, p. 77-81, 2009.

BLOCH, E. O Princípio Esperança. v. I. Rio de Janeiro: Ed. UERJ/Contraponto, 2005.

BUTLER. J. Problemas de gênero: feminismo e subversão da identidade. 13. ed. Rio de Janeiro: Civilização Brasileira, 2017.

CONNELL, R. W. Masculinities. 2. ed. Berkeley/Los Angeles: University of California Press, 2005.

CONNELL, R. W. Understanding men: gender sociology and the new international research on masculinities. Social Thought \& Research, Lawrence: University of Kansas, v. 24, n. 1-2, p. 13-31, 2002.

CONNELL, R. W. Políticas da masculinidade. Educação \& Realidade, Porto Alegre: Universidade Federal do Rio Grande do Sul, v. 20, n. 2, p. 185-206, 1995.

CONNELL, R. W.; MESSERSCHMIDT, J. W. Masculinidade hegemônica: repensando o conceito. Estudos Feministas, Florianópolis: UFSC, v. 21, n. 1, p. 241-282, 2013.

COUTO, M. Cada homem é uma raça. São Paulo: Companhia das Letras, 2013.

COUTO, M. Estórias abensonhadas. São Paulo: Companhia das Letras, 2012a.

COUTO, M. A confissão da leoa. São Paulo: Companhia das Letras, 2012b.

COUTO, M. Antes de nascer o mundo. São Paulo: Companhia das Letras, 2009a.

COUTO, M. O fio das missangas. São Paulo: Companhia das Letras, 2009b. 
COUTO, M. Cronicando. 2. ed. Maputo: Ndjira, 2008.

COUTO, M. Terra sonâmbula. São Paulo: Companhia das Letras, 2007.

COUTO, M. O último voo do flamingo. São Paulo: Companhia das Letras, 2005.

COUTO, M. Um rio chamado tempo, uma casa chamada terra. São Paulo: Companhia das Letras, 2003.

DOUBROVSKY, J. S. O último eu. In: NORONHA, J. M. G. (org.). Ensaios sobre a autoficção. Belo Horizonte: Ed. UFMG, 2014. p. 111-125.

FOUCAULT, M. História da Sexualidade: I. A vontade de saber. 13. ed. Rio de Janeiro: Graal, 1999.

HALL, S. Da Diáspora: identidades e mediações culturais. Belo Horizonte: Ed. UFMG/ UNESCO, 2003.

ONDJAKI. Os transparentes. São Paulo: Companhia das Letras, 2013.

ONDJAKI. A bicicleta que tinha bigodes. Rio de Janeiro: Pallas, 2012.

ONDJAKI. Quantas madrugadas tem a noite. São Paulo: Leya, 2010.

ONDJAKI. AvóDezanove e o segredo do soviético. São Paulo: Companhia das Letras, 2009.

ONDJAKI. Os da minha rua. Rio de Janeiro: Língua Geral, 2007.

ONDJAKI. Bom dia camaradas. Rio de Janeiro: Agir, 2006.

RUFFATO, L. Bom dia, camarada leitor brasileiro! In: ONDJAKI. Bom dia camaradas. Rio de Janeiro: Agir, 2006. p. 09-13.

SARLO, B. Tempo passado: cultura da memória e guinada subjetiva. São Paulo/Belo Horizonte: Companhia das Letras/UFMG, 2007.

SARTRE, J. P. Que é a literatura? 3. ed. São Paulo: Ática, 2004. 
SEDGWICK, E. K. Between Men: English Literature and Male Homosocial Desire. New York: Columbia University, 1985.

SEIGWORTH, G. J.; GREGG, M. An inventory of shimmers. In: AHMED, S. The affect theory reader. Durham/London: Duke University Press, 2010. p. 01-25.

VIEIRA, J. L. João Vêncio: os seus amores. 2. ed. Lisboa: Edições 70, 1987. 